\title{
Leukocytes respiratory burst activity as indicator of innate immunity of pacu Piaractus mesopotamicus
}

\author{
Biller-Takahashi, JD. ${ }^{a *}$,Takahashi, LS. ${ }^{b}$, Saita, MV. ${ }^{a}$, Gimbo, RY. ${ }^{a}$ and Urbinati, EC. ${ }^{a, c}$ \\ ${ }^{\text {a}}$ Faculdade de Ciências Agrárias e Veterinárias, Universidade Estadual Paulista - UNESP, \\ CEP 14884-900, Jaboticabal, SP, Brazil \\ ${ }^{b}$ Faculdade de Zootecnia, Universidade Estadual Paulista - UNESP, CEP 17900-000, Dracena, SP, Brazil \\ ${ }^{c}$ Centro de Aquicultura - CAUNESP, Universidade Estadual Paulista - UNESP, CEP 14884-900, Jaboticabal, SP, Brazil \\ *e-mail: jaque.biller@yahoo.com.br
}

Received April 4, 2012 - Accepted May 30, 2012 - Distributed May 31, 2013

(With 1 Figure)

\begin{abstract}
The present study evaluated the assay to quantify the respiratory burst activity of blood leukocytes of pacu as an indicator of the innate immune system, using the reduction of nitroblue tetrazolium (NBT) to formazan as a measure of the production of reactive oxygen species (ROS). In order to assess the accuracy of the assay, fish were challenged by Aeromonas hydrophila and sampled one week after challenge. The A. hydrophila infection increased the leukocyte respiratory burst activity. The protocol showed a reliable and easy assay, appropriate to determine the respiratory burst activity of blood leukocytes of pacu, a neotropical fish, in the present experimental conditions.
\end{abstract}

Keywords: immune methodology, fish immunology, cellular immunity.

\section{Atividade respiratória de leucócitos como indicador de imunidade inata de pacu (Piaractus mesopotamicus)}

\begin{abstract}
Resumo
O presente estudo avaliou o ensaio para quantificar a atividade respiratória dos leucócitos do sangue de pacu como um indicador do sistema imune inato, usando a redução do nitroazul tetrazólio (NBT) a formazan como medida da produção de espécies reativas de oxigênio (EROs). Para avaliar a precisão do ensaio, peixes foram desafiados por Aeromonas hydrophila e amostrados uma semana após o desafio. A infecção com A. hydrophila aumentou a atividade respiratória dos leucócitos. O protocolo se mostrou confiável e de fácil aplicação, apropriado para determinar a atividade respiratória de leucócitos do sangue do pacu, peixe neotropical, nas condições experimentais apresentadas.
\end{abstract}

Palavras-chave: metodologia, imunidade de peixe, imunidade mediada por células.

\section{Introduction}

Leukocytes respiratory burst activity as an indicator of innate immunity was first observed in mammals in the 1930s when some researchers realized that phagocytosis was linked with elevated oxygen consumption (Baldridge and Gerard, 1933). Nowadays, respiratory burst is also correlated with cytokines release and inflammatory response in fish (Neumann et al., 2000a; Rieger et al., 2010).

One of the most important mechanisms of fish defense is the phagocytosis and some cells are able to destroy invading particles besides processing and introducing them to the specific cells that will promote immunoglobulin production (Neumann et al., 2000b). Monocytes, macrophages and neutrophils are professional phagocytes; however other cells can perform phagocytosis so that the cell requires the detection of the foreign particle through membrane receptors. Cytokines, molecular signals of inflammation, are released by those phagocytes at the inflammation

site by injured tissue so as to promote chemotaxis and phagocyte mobilisation (Stuart and Ezekowitz, 2005; Mathias et al., 2009).

During the phagocytosis of pathogens, leukocytes increase their oxygen consumption through the NADPH oxidase and generate various reactive oxygen species (ROSs) such as the superoxide anion radical $\left(\mathrm{O}_{2}\right)$, hydrogen peroxide $\left(\mathrm{H}_{2} \mathrm{O}_{2}\right)$, singlet oxygen $\left({ }^{1} \mathrm{O}_{2}\right)$ and the hydroxyl radical $\left(\mathrm{OH}^{-}\right)$in a process called the respiratory burst. Superoxide and hydrogen peroxide are highly toxic ROSs and form the basis of a potent antibacterial system (Klebanoff, 1999). The quantity of reactive oxygen species can differ during the periods of the year, as well as the day so that it is influenced and regulated by temperature as well as the circadian rhythms (Kaplan et al., 2008; Buchtíková et al., 2011). 
The pacu, Piaractus mesopotamicus (Holmberg, 1887) is one of the most important fish in Brazilian aquaculture (Roubach et al., 2003) and widely studied for different issues (Barreto et al., 2010; Fujimoto et al., 2010; Jerônimo et al., 2011). Its farming has grown in the last decade with an annual production around 12,400 tons (Ibama, 2005). However, the intensification of fish culture may cause disease outbreaks by Aeromonas hydrophila (Cipriano, 2001), a Gram-negative bacterium widely distributed in aquatic environments that causes Hemorrhagic Septicemia in a great diversity of freshwater fish and rarely in marine fish. Among fish pathogens, A. hydrophila has been responsible for large economic losses worldwide (Paniagua et al., 1990; Sahoo et al., 2008; Reyes-Becerril et al., 2011). This bacterium is considered a secondary opportunistic pathogen due to promotion of disease in immune suppressed fish (Tellez et al., 2010). Several studies have already applied this pathogen injection as an effective mechanism of fish immune responses modification, since the fish innate defense system can be triggered in an unspecific way by extracellular and intracellular microorganism compounds as well as toxins of $A$. hydrophila (Rodríguez et al., 2008; Sahoo et al., 2008).

The respiratory burst activity of phagocytes has been used frequently as an indicator of nonspecific immunity in fish (Anderson and Siwicki, 1995; Sahoo and Mukherjee, 2002; Sahoo et al., 2005). Regarding Brazilian native fish species, very little is known on its innate immune responses (Belo et al., 2005; Abreu et al., 2009; Sado et al., 2010; Biller-Takahashi et al., 2012). However, the appropriate assessment of the immune responses demands a reliable methodology. Thus, in order to support future studies on the immune system of neotropical native fish with appropriate analytical methods, the present study has optimised the assay to measure the reactive oxygen species (ROSs) produced during the leukocytes respiratory burst activity of pacu challenged with A. hydrophila.

\section{Material and Methods}

A total of 144 pacu $(69.9 \pm 28 \mathrm{~g})$ was distributed in 18 1001 tanks ( 8 fish per tank) with a continuous water and air flow system. The water quality parameters were monitored daily and were within the values described for this species (Urbinati et al., 2010): temperature $26.0 \pm 0.39^{\circ} \mathrm{C}$, dissolved oxygen $5.6 \pm 0.57 \mathrm{mg} \mathrm{L}^{-1}$ and $\mathrm{pH} 7.6 \pm 0.09$. Fish were kept in these conditions during 20 days for acclimatisation, being fed to apparent satiation with commercial diet $(28 \%$ protein, $3 \%$ fat, $1 \%$ fiber) in two daily meals.

Fish were randomly divided into 2 groups, one group sampled before the bacterial challenge and the other group sampled after the pathogen injection (nine tanks for each group). After the acclimatisation period, fish (two fish per tank) were anesthetised in benzocaine $\left(0.1 \mathrm{~g} \mathrm{~L}^{-1}\right)$ and whole blood was collected from caudal vessels with a heparinised syringe. Sampled fish were not reusable. The remaining fish in each tank (54 fish per treatment) were anesthetised and inoculated with a A. hydrophila injection, intraperitoneally. The bacterium was obtained according to Garcia and Moraes (2009) and fish were challenged

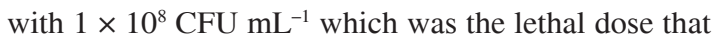
causes $50 \%$ of fish death, LD50 (Plumb and Bowser, 1983). Seven days after challenge, surviving fish of all treatments (two fish per tank) were sampled as described before. Blood was collected and immediately processed to assay the leukocytes respiratory burst activity. The assay was carried out following the Anderson and Siwicki (1995) protocol, with modifications. The method consists of a colorimetric determination of the ROSs produced by the leukocytes respiratory burst, which promotes reduction of nitroblue tetrazolium (NBT, Sigma, St. Louis, MO, USA) into dark blue precipitate inside the phagocyte, called formazan granules.

After fish bleeding, $100 \mu \mathrm{L}$ of heparinised blood was added to $100 \mu \mathrm{L}$ of $0.2 \%$ nitroblue tetrazolium solution (NBT, Sigma, St. Louis, MO, USA) and the final solution was homogenised and incubated for 30 minutes at $25^{\circ} \mathrm{C}$. The NBT solution was prepared in phosphate buffered saline (PBS, prepared with $\mathrm{NaCl}(0.137 \mathrm{M}), \mathrm{KCl}(2.7 \mathrm{mM})$, $\mathrm{KH}_{2} \mathrm{PO}_{4}(1.5 \mathrm{mM}), \mathrm{Na}_{2} \mathrm{HPO}_{4}(8.1 \mathrm{mM}), \mathrm{CaCl}_{2}(0.9 \mathrm{mM})$, $\mathrm{MgCl}_{2}(0.49 \mathrm{mM})$ in distilled water Milli-Q qsp 1 litre), $\mathrm{pH}$ 7.4. After incubation and a second homogenisation, $50 \mu \mathrm{L}$ from the solution were added to $1 \mathrm{ml}$ of $\mathrm{N}, \mathrm{N}$-dimethyl formamide (DMF, Sigma, St. Louis, MO, USA) in a glass tube. This new solution was homogenised and centrifuged at $3000 \mathrm{~g}$ for 5 minutes. The optical density (OD) of supernatant was determined on spectrophotometer (Beckman DU-70S) at $540 \mathrm{~nm}$. The blank consisted of the same components and steps except blood that was exchanged with distilled water.

Data were submitted to one-way ANOVA. If results were significant, a Tukey test was applied for means comparisons. Differences were considered significant at $p<0.05$.

\section{Results and Discussion}

The present study optimised the assay to quantify the respiratory burst activity of pacu leukocytes, using the reduction of nitroblue tetrazolium (NBT) to formazan as a measure of superoxide anions production as described by Anderson and Siwicki (1995). This is the first study to assess the respiratory activity of blood leukocytes in a neotropical native fish in response to a bacterial infection. The assay evaluates the ability of phagocytes to produce ROSs that attack the pathogens membranes and protect the fish body. In order to assess the accuracy of the assay, the study used fish challenged by $A$. hydrophila as a mechanism of fish immune system manipulation.

A previous study described a different leukocyte respiratory assay for pacu (Abreu et al., 2009) based on chemiluminescence observed in stained blood smears with Leishman's solution in order to determine the percent of cells containing intracellular blue formazan particles under light microscopy. In this new approach, the NBT reduction 
was measured colorimetrically in a dissolved solution, resulting in an easier, cheaper and more sensitive assay.

The assay also showed the pathogen injection to be an effective mechanism of activation of fish innate immunity as seen in Figure 1. The leukocyte respiratory burst activity increased after the pathogen injection, indicating that phagocytes enhanced the production of ROSs by activating the NADPH oxidase enzyme that produces oxygen peroxide (Klebanoff, 1999).

White blood cells of teleosts, including thrombocytes and leukocytes, are responsible for body defense (Hrubec and Smith, 2000; Martins et al., 2009). The phagocytosis is one of the most effective mechanisms for destroying invasive pathogens and for protection against disease outbreaks due to its immediate action that is a characteristic of innate defense (Neumann et al., 2000b). The leukocyte respiratory burst assay, optimised in this study, is a reliable tool to measure the ROSs produced during phagocytosis and can be applied in any study that evaluates the immune system.

In teleost fish, the innate immune system is the first mechanism activated in defense against invading pathogens, and it is considered more important than the specific system, playing an important role for host survival. Intracellular soluble substances, such as ROSs, supply the fish body with humoral innate protection against either phagocyted pathogens or pathogens that had invaded the host cell. The ROSs compounds are remarkably toxic to both microorganisms and host cells since its action is usually nonspecific, but since pathogen and the ROSs are kept inside the cell membrane, it guarantees decreased damage to host phagocytes (Morel et al., 1991; Stuart and Ezekowitz, 2005; Rieger and Barreda, 2011).

The interaction of ROSs production and infection has been studied due to its importance in the activation of the immune system (Reyes-Becerril et al., 2011a). Regarding the increased ROSs production by granulocytes, it has been considered an indicator of the innate immune system activation (Jeney and Anderson, 1993; Jorgensen and Robertsen, 1995). In this way, pacu challenged by A. hydrophila have shown improvement in ROSs production and increased protection against pathogens, assessed by the respiratory burst assay. The activation of immune mechanisms carries out an important function in preventing

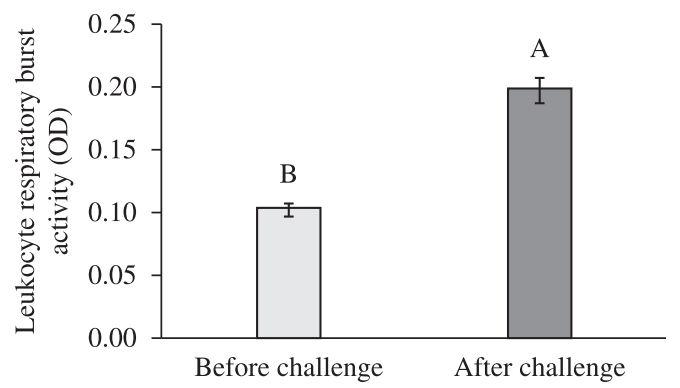

Figure 1. Leukocytes respiratory burst activity (means \pm SMD) of pacu (Piaractus mesopotamicus). Significant differences are indicated by different letters $(p \leq 0.5)$. disease in fish and several studies have evaluated these fish responses after pathogen infection (Rodríguez et al., 2008; Raida and Buchmann, 2009; Mohanty and Sahoo, 2010; Reyes-Becerril et al., 2011b).

Reyes-Becerril et al. (2011a) evaluated the alterations in cellular innate immune parameters of Sparus aurata double injected with the Gram-negative bacteria A. hydrophila, causative agent of septicaemia. The authors injected $A$. hydrophila twice, first injection with $1 \times 10^{7}$ cell m $\mathrm{m}^{-1}$ and the second with $1 \times 10^{8}$ cell $\mathrm{mL}^{-1}$, and found mainly respiratory burst activity increasing after the second infection, indicating recovery of the immune system after pathogen exposition.

In conclusion, the standardised colorimetric assay for determination of leucocytes respiratory burst activity in pacu showed to be reliable and easy to perform, generating a valuable tool for the assessment of the innate immune system of this neotropical native Brazilian species. Additionally, the pathogen infection was an effective alternative in order to activate and increase the ROSs production by leukocytes of pacu.

Acknowledgements - The authors thank the financial support provided by CAPES.

\section{References}

ABREU, JS., MARZOCCHI-MACHADO, CM., URBACZEK, AC., FONSECA, LM. and URBINATI, EC., 2009. Leukocytes respiratory burst and lysozyme level in pacu (Piaractus mesopotamicus). Brazilian Journal of Biology, vol. 69, no. 4, p. 1133-9. PMid:19967185. http://dx.doi.org/10.1590/S151969842009000500018

ANDERSON, DP. and SIWICKI, AK., 1995. Basic haematology and serology for fish health programs. In SHARIFF, M., ARTHUR, JR., SUBASINGHE, RP. (Eds.). Diseases in Asian aquaculture II. Fish Health Section. Manila: Asian Fisheries Society. p. 185-202.

BALDRIDGE, CW. and GERARD, RW., 1933. The extra respiration of phagocytosis. American Journal of Physiology, vol. 103 , no. 1 , p. 235-6.

BARRETO, LEG., IGARASHI, MA. and HAYASHI, C., 2010. Nictemeral Variations for Pacu Caranha, Piaractus mesopotamicus (Holmberg, 1887) Culture in Single - Phase. Brazilian Archives of Biology and Technology, vol. 53, no. 4, p. 873-881. http://dx.doi. org/10.1590/S1516-89132010000400017

BELO, MAA., SCHALCH, SHC., MORAES, FR., SOARES, VE., OTOBONI, A. and MORAES, JRE., 2005. Effect of dietary supplementation with vitamin $\mathrm{E}$ and stocking density on macrophage recruitment and giant cell formation in teleost fish Piaractus mesopotamicus. Journal of Comparative Pathology, vol. 133, no. 2-3, p. 146-154. PMid:16033696. http://dx.doi. org/10.1016/j.jcpa.2005.04.004

BILLER-TAKAHASHI, JD., TAKAHASHI, LS., MARZOCCHIMACHADO, CM., ZANUZZO, FS. and URBINATI, EC., 2012. Hemolytic activity of alternative complement system as an indicator of innate immunity in pacu (Piaractus mesopotamicus). Revista Brasileira de Zootecnia, vol. 41, no. 2, p. 237-241. http://dx.doi. org/10.1590/S1516-35982012000200001

BUCHTÍKOVÁ, S., SIMKOVÁ, A., ROHLENOVÁ, K., FLAJSHANS, M., LOJEK, A., LILIUS, EM. and HYRS, P., 2011. 
The seasonal changes in innate immunity of the common carp (Cyprinus carpio). Aquaculture, vol. 318, no. 1-2, p. 169-175. http://dx.doi.org/10.1016/j.aquaculture.2011.05.013

CIPRIANO, RC., 2001. Aeromonas hydrophila and motile Aeromonad septicemias of fish. In Fish Disease. Washington: United States Department of the Interior Fish and Wildlife Service, Division of Fishery Research; p.1-25.

FUJIMOTO, RY., CASTRO, MP., MARTINS, ML., MORAES, FR., VARELLA, JEA. and DINIZ, DG., 2010. Effects of Chromium Supplementation on the infra populations of Anacanthorus penilabiatus (Monogenoidea) and Piscinoodinium pillulare (Dinoflagellida) Parasites of Piaractus mesopotamicus (Characidae). Brazilian Archives of Biology and Technology, vol. 53, no. 4, p. 827-833. http://dx.doi.org/10.1590/S1516-89132010000400011

GARCIA, F. and MORAES, FR., 2009. Hematologia e sinais clínicos de Piaractus mesopotamicus infectados experimentalmente com Aeromonas hydrophila. Acta Scientiarum. Biological Sciences, vol. 31 , no. 1, p. 17-21.

HRUBEC, TC. and SMITH, SA., 2000. Hematology of fish. In Feldman BV, Zinkl JG, Jain NC, editor. Schalm's veterinary hematology. Philadelphia: Lippincott Williams and Wilkins. p. 1120-5.

Instituto Brasileiro do Meio Ambiente e dos Recursos Naturais Renováveis - IBAMA. Estatística Pesqueira do Brasil. 2005. Available from: http://www.ibama.gov.br.

JENEY, G. and ANDERSON, DP., 1993. Glucan injection or bath exposure given alone or in combination with a bacterin enhance the non-specific defence mechanisms in rainbow trout (Oncorhynchus mykiss). Aquaculture, vol. 116, no. 4, p. 315-329. http://dx.doi.org/10.1016/0044-8486(93)90416-V

JERÔNIMO, GT., LAFFITTE, LV., SPECK, GM. and MARTINS, ML., 2011. Seasonal influence on the hematological parameters in cultured Nile tilapia from southern Brazil. Brazilian Journal of Biology, vol. 71, no. 3, p. 719-725. PMid:21881796. http:// dx.doi.org/10.1590/S1519-69842011000400017

JORGENSEN, JB. and ROBERTSEN, B., 1995. Yeast $\beta$-glucan stimulates respiratory burst activity of Atlantic Salmon (Salmo salar L.) macrophages. Developmental and Comparative Immunology, vol. 19, no. 1, p. 43-57. http://dx.doi.org/10.1016/0145305X(94)00045-H

KAPLAN, JE., CHRENEK, RD., MORASH, JG., CATARINA, M., RUKSZNIS, L. and HANNUM, G., 2008. Rhythmic patterns in phagocytosis and the production of reactive oxygen species by zebrafish leukocytes. Comparative and Biochemistry Physiology. A: Molecular and Integrative Physiology, vol. 151, no. 4, p. 726-730. PMid:18793741. http://dx.doi.org/10.1016/j.cbpa.2008.08.030

KLEBANOFF, SJ., 1999. Oxygen metabolites from phagocytes. In GALLIN, JI. and SNYDERMAN, R. (Eds.). Inflammation: Basic principles and clinical correlates. Philadelphia: Lippincott Williams and Wilkins. p. 721-768.

MARTINS, ML., MYIAZAKI, DMY., TAVARES-DIAS, M., FENERICK-JUNIOR, J., ONAKA, EM., BOZZO, FR., FUJIMOTO, RY. and MORAES, FR., 2009. Characterization of the acute inflammatory response in the hybrid tambacu (Piaractus mesopotamicus male $\times$ Colossoma macropomum female) (Osteichthyes). Brazilian Journal of Biology, vol. 69, no. 3, p. 957-962. PMid:19802458.

MATHIAS, JR., DODD, ME., WALTERS, KB., YOO, SK., RANHEIM, EA., HUTTENLOCHER, A., 2009. Characterization of zebrafish larval inflammatory macrophages. Developmental and Comparative Immunology, vol. 33, no. 11, p. 1212-1217. PMid:19619578 PMCid:2742687. http://dx.doi.org/10.1016/j. dci.2009.07.003

MOHANTY, BR. and SAHOO, PK., 2010. Immune responses and expression profiles of some immune-related genes in Indian major carp, Labeo rohita to Edwardsiella tarda infection. Fish and Shellfish Immunology, vol. 28, no. 4, p. 613-621. PMid:20045061. http://dx.doi.org/10.1016/j.fsi.2009.12.025

MOREL, F., DOUSSIERE, J. and VIGNAIS, PV., 1991. The superoxide generating oxidase of phagocytic cells. Physiological, molecular and pathological aspects. European Journal of Biochemistry, vol. 201, no. 3, p. 523-546. PMid:1657601. http:// dx.doi.org/10.1111/j.1432-1033.1991.tb16312.x

NEUMANN, NF., BARREDA, DR. and BELOSEVIC, M., 2000a. Generation and functional analysis of distinct macrophage subpopulations from goldfish (Carassius auratus L.) kidney leukocyte cultures. Fish and Shellfish Immunology, vol. 10, no. 1, p. 1-20. PMid:10938719. http://dx.doi.org/10.1006/fsim.1999.0221

NEUMANN, NF., STAFFORD, JL., BARREDA, D., AINSWORTH, AJ. and BELOSEVIC, M., 2000b. Antimicrobial mechanisms of fish phagocytes and their role in host defense. Developmental and Comparative Immunology, vol. 25, no. 8-9, p. 807-825.

PANIAGUA, C., RIVERO, O. and ANGUITA, J., 1990. Pathogenicity factors and virulence for rainbow trout (Salmo gairdneri) of motile Aeromonas spp. isolated from a river. Journal of Clinical Microbiology, vol. 28, no. 2, p. 350-355. PMid:2312678 PMCid:269605.

PLUMB, JA. and BOWSER, PR., 1983. Microbial fish disease laboratory manual. Alabama: Agricultural Experiment Station. Auburn University.

RAIDA, MK. and BUCHMANN, K., 2009. Innate immune response in rainbow trout (Oncorhynchus mykiss) against primary and secondary infections with Yersinia ruckeri O1. Developmental and Comparative Immunology, vol. 33, no. 1, p. 35-45.

REYES, BM., LÓPEZ, MT., ASCENCIO, VF. and ESTEBAN, M., 2011a. Immune response of gilthead seabream (Sparus aurata) following experimental infection with Aeromonas hydrophila. Fish and Shellfish Immunology, vol. 31, no. 4, p. 564-570. PMid:21767651.

REYES, BM., TOVAR, RD., ASCENCIO, VF., CIVERACERECEDO, R., GRACIA-LOPEZ, V. and BARBOSA-SOLOMIEU, V. and ESTEBAN, MA., 2011b. Effects of dietary supplementation with probiotic live yeast on the immune and antioxidant systems of leopard grouper Mycteroperca rosacea infected with Aeromonas hydrophila. Aquaculture Research, vol. 42, no. 11, p. 1676-1686. http://dx.doi.org/10.1111/j.1365-2109.2010.02762.x

RIEGER, AM. and BARREDA DR., 2011. Antimicrobial mechanisms of fish leukocytes. Developmental and Comparative Immunology, vol. 35, no. 12, p. 1238-1245. PMid:21414350. http://dx.doi.org/10.1016/j.dci.2011.03.009

RIEGER, AM., HALL, BE. and BARREDA, DR., 2010. Macrophage activation differentially modulates particle binding, phagocytosis and downstream antimicrobial mechanisms. Developmental and Comparative Immunology, vol. 34, no. 11, p. 1144-1159. PMid:20600280. http://dx.doi.org/10.1016/j.dci.2010.06.006

RODRÍGUEZ, I., NOVOA, B. and FIGUERAS, A., 2008. Immune response of zebrafish (Danio rerio) against a newly isolated bacterial pathogen Aeromonas hydrophila. Fish and Shellfish 
Immunology, vol. 25, no. 3, p.239-249. PMid:18640853. http:// dx.doi.org/10.1016/j.fsi.2008.05.002

ROUBACH, R., CORREIA, ES., ZAIDEN, SF., MARTINO, RC. and CAVALLI, RO., 2003. Aquaculture in Brazil. World Aquaculture, vol. 34, no. 1, p. 28-34.

SADO, RY., BICUDO, AJA. and CYRINO, JEP., 2010. Dietary levamisole influenced hematological parameters of juvenile pacu, Piaractus mesopotamicus (Holmberg 1887). Journal of World Aquaculture Society, vol. 41, no. 1, p. 66-75.

SAHOO, PK., DAS MAHAPATRA, K., SAHA, JN., BARAT, A., SAHOO, M., MOHANTY, BR., GJERDE, B., ODEGARD, J., RYE, M. and SALTE, R., 2008. Family association between immune parameters and resistance to Aeromonas hydrophila infection in the Indian major carp, Labeo rohita. Fish and Shellfish Immunology, vol. 25, no. 1-2, p. 163-9. PMid:18486488. http:// dx.doi.org/10.1016/j.fsi.2008.04.003

SAHOO, PK., KUMARI, J. and MISHRA, BK., 2005. Nonspecific immune responses in juveniles of Indian major carps. Journal of Applied Ichthyology, vol. 21, no. 2, p. 151-5. http:// dx.doi.org/10.1111/j.1439-0426.2004.00606.x
SAHOO, PK. and MUKHERJEE, SC., 2002. The effect of dietary immunomodulation upon Edwardsiella tarda vaccination in healthy and immunocompromised Indian major carp (Labeo rohita). Fish and Shellfish Immunology, vol. 12, no. 1, p. 1-16. PMid:11866127. http://dx.doi.org/10.1006/fsim.2001.0349

STUART, LM. and EZEKOWITZ, RAB., 2005. Phagocytosis: elegant complexity. Immunity, vol. 22, no. 5, p. 539-550. PMid: 15894272. http://dx.doi.org/10.1016/j.immuni.2005.05.002

TELLEZ, BMC., SANTERRE, A., CASAS-SOLIS, J. and ZAITSEVA, G., 2010. Endosulfan increases seric interleukin-2 like (IL-2L) factor and immunoglobulin M (IgM) of Nile tilapia (Oreochromis niloticus) challenged with Aeromonas hydrophila. Fish and Shellfish Immunology, vol. 28, no. 2, p. 401-5. PMid:19944172. http://dx.doi.org/10.1016/j.fsi.2009.11.017

URBINATI, EC. and CARNEIRO, PCF., 2004. Práticas de manejo e estresse dos peixes em piscicultura. In CYRINO, JEP., URBINATI, EC., FRACALOSSI, DM., CASTAGNOLLI, N. (Eds.). Tópicos especiais em piscicultura de água doce tropical intensiva. São Paulo: TecArt, Sociedade Brasileira de Aqüicultura e Biologia Aquática. p.171-194. 